\title{
Induction of avian $\beta$-defensins by CpG oligodeoxynucleotides and proinflammatory cytokines in hen vaginal cells in vitro
}

\author{
Yuka Sonoda ${ }^{1}$, Ahmad M Abdel Mageed ${ }^{1,2}$, Naoki Isobe ${ }^{1}$ and Yukinori Yoshimura ${ }^{1}$ \\ ${ }^{1}$ Graduate School of Biosphere Science, Hiroshima University, Higashi-Hiroshima 739-8528, Japan and ${ }^{2}$ Faculty of \\ Science, Minia University, Minia 61519, Egypt \\ Correspondence should be addressed to Y Yoshimura; Email: yyosimu@hiroshima-u.ac.jp
}

\begin{abstract}
Immune function in the vagina of hen oviduct is essential to prevent infection by microorganisms colonizing in the cloaca. The aim of this study was to determine whether CpG oligodeoxynucleotides (CpG-ODN) stimulate the expression of avian $\beta$-defensins ( $A v B D s$ ) in hen vaginal cells. Specific questions were whether CpG-ODN affects the expression of $A v B D$ s and proinflammatory cytokines and whether the cytokines affect $A v B D$ s expression in vaginal cells. The dispersed vaginal cells of White Leghorn laying hens were cultured and stimulated by different doses of lipopolysaccharide (LPS), CpG-ODN, interleukin $1 \beta$ (IL1B), or IL6. The cultured cell population contained epithelial cells, fibroblast-like cells, and CD45-positive leukocytes. The immunoreactive AvBD3, -10, and -12 were localized in the mucosal epithelium in the section of the vagina. The expression of $A v B D s, I L 1 B$, and IL6 was analyzed by quantitative RT-PCR. RT-PCR analysis showed the expression of $A v B D 1,-3,-4,-5,-10$, and -12 in the cultured vaginal cells without stimulation. Toll-like receptors (TLRs) 4 and 21, which recognize LPS and CPG-ODN respectively and IL1 and IL6 receptors (IL1R1 and IL6R) were also expressed in them. The expression of ILIB, IL6, and $A v B D 10$ and -12 was upregulated by LPS, whereas only IL1B and IL6 were upregulated by CpG-ODN. IL1B stimulation upregulated $A v B D 1$ and -3 expression, whereas IL6 stimulation did not cause changes in $A v B D s$ expression. These results suggest that CPG-ODN derived from microbes upregulates the expression of IL1B and IL6 by interaction with TLR21 and then IL1B induces $A v B D 1$ and -3 to prevent infection in the vagina.
\end{abstract}

Reproduction (2013) 145 621-631

\section{Introduction}

In hens, the vagina opens to the cloaca where various microorganisms colonize. The host defense functions of the vagina play essential roles to prevent infection by these microorganisms ascending the oviduct. Toll-like receptors (TLRs) that recognize pathogen-associated molecular patterns initiate innate immune responses. To date, ten TLRs have been identified in chickens (Brownlie \& Allan 2011). Among them, TLR4 recognizes lipopolysaccharide (LPS), which is a major component of the outer membrane of Gram-negative bacteria. CpG oligodeoxynucleotide (CpG-ODN) containing unmethylated $\mathrm{CpG}$ motifs is conserved in the genomic DNA in bacteria (Krieg et al. 1995, Wagner 1999). The CpG-ODN is recognized by TLR9 in mammals (Hemmi et al. 2000, Bauer et al. 2001), whereas TLR21 acts as a functional homolog to mammalian TLR9 in the recognition of CpG-ODN in chickens (Brownlie et al. 2009). The expression of proinflammatory cytokines, interferon (IFN) $\gamma$, and nitric oxide was found to be induced in response to CpG-ODN in mononuclear cells and splenocytes in chickens (He et al. 2003, Patel et al. 2008). However, it is unknown whether an immune response is induced by $\mathrm{CpG-ODN}$ in the mucosal tissue of hen vagina.

Defensins, antimicrobial peptides, are cysteine-rich cationic peptides (Selsted \& Ouellette 2005). The avian $\beta$-defensins (AvBDs) are characterized by six cysteine residues, and $14 A v B D$ s genes have been identified in chickens (Lynn et al. 2007). They have the potential to kill a wide spectrum of microorganisms, including Gram-positive and Gram-negative bacteria, fungi, and yeasts (Yang et al. 2002, Sugiarto \& Yu 2004). Proinflammatory cytokines such as interleukin $1 \beta$ (IL1B) and IL6 also play important roles in innate and adaptive immune systems and induce inflammatory responses in infected tissue (Staeheli et al. 2001, Ferro et al. 2004). IL1B was shown to enhance the production of immune-related molecules, such as nitric oxide, acute-phase proteins, cytokines, and chemokines (Arend et al. 2008). IL6 has multiple functions, such as stimulation of antibody synthesis by B cells (Okada et al. 1983) and the differentiation of monocytes from dendritic cells to macrophages (Chomarat et al. 2000). We have reported that the injection of birds with LPS enhanced the expression of both $A v B D s$ and proinflammatory cytokines, ILIB and IL6, in the vagina 
(Abdel Mageed et al. 2008, Nii et al. 2011). In mammals, there are reports that $\beta$-defensin expression was upregulated by IL1B in keratinocytes, and in corneal and uterus epithelium (Liu et al. 2002, McDermott et al. 2003, Shin et al. 2004, Pioli et al. 2006). If CpG-ODN was shown to enhance AvBDs expression, this would provide a novel understanding of the process of AvBDs induction in response to bacterial components in the vagina. For further determination of the mechanism by which AvBDs expression is regulated downstream of CpG-ODN stimulation, the role of proinflammatory cytokines that may be expressed by CpG-ODN in AvBDs expression should also be examined.

The aim of this study was to determine whether CpG-ODN leads to an increase in the $A v B D$ s expression in hen vagina. In experiment 1 , the effects of LPS and CpG-ODN on the expression of ILIB, IL6, and $A v B D$ s in cultured vaginal cells were examined. This experiment examined whether CpG-ODN induces the expression of $A v B D s$ and proinflammatory cytokines and whether there are differences in the effects of their induction between CpG-ODN and LPS. Then, in experiment 2, the effects of IL1B and IL 6 on the $A v B D$ s expression in those cells were examined. The induction of AvBDs by these proinflammatory cytokines was analyzed to know the possibility that CpG-ODN induces the cytokines and then they affect $A v B D$ s expression.

\section{Results}

Figure 1 shows the pattern of RT-PCR products of $A v B D$, TLR4 and TLR21, and IL1 and IL6 receptors (ILIR1 and $I L 6 R)$ in vaginal mucosa cells cultured for $24 \mathrm{~h}$. Clear bands of six $A v B D s$ including $A v B D 1, A v B D 3-5$, $A v B D 10$, and $A v B D 12$ were identified (Fig. 1a). Thus, the changes in the expression of these six $A v B D s$ in response to LPS, CpG-ODN, IL1B, and IL6 were examined in experiments 1 and 2. The PCR products of TLR4 and TLR21, and ILIR1 and IL6R, were also identified (Fig. 1b and c). The cultured cell population contained epithelial cells including the cells positive for Alcian blue and Periodic acid-Schiff reaction (AB-PAS), elongated fibroblast-like cells, and CD45-positive leukocytes (Fig. 1d and e). The immunoreaction products for AvBD3, -10, and -12 were identified in the mucosal epithelium in the section of the vagina (Fig. 2a, b, and c), but the negative control staining using normal rabbit IgG did not show any immunoreaction products (Fig. 2d).

\section{Experiment 1: effects of $L P S$ and CpG-ODN on the expression of IL1B, IL6, and AvBDs in vaginal cells}

Figure 3 shows the changes in the expression of IL $1 B$, IL6, and $A v B D s$ in the vaginal cells stimulated by different doses of LPS. The IL1B expression was significantly higher at $\sim 17$-fold in the $10^{2} \mathrm{ng} / \mathrm{ml}$ LPS group and was also higher in the $10^{3}$ and $10^{4} \mathrm{ng} / \mathrm{ml}$ LPS groups compared with that in the control $(0 \mathrm{ng} / \mathrm{ml}$ LPS) (Fig. 3a). The IL6 expression was significantly upregulated by $10^{4} \mathrm{ng} / \mathrm{ml}$ LPS (Fig. 3b). The expression of $A v B D 1,-3,-4$, and -5 was not affected by LPS stimulation (Fig. 3c, d, e, and f). However, the expression of AvBD10 was significantly higher at approximately fourfold in the $10^{2} \mathrm{ng} / \mathrm{ml}$ LPS group compared with that in the control, but this was not caused by a higher dose of LPS (Fig. 3g). $A v B D 12$ expression was also significantly higher in the $10^{4} \mathrm{ng} / \mathrm{ml}$ LPS group than in the control (Fig. 3h).

The effects of different doses of CpG-ODN on the expression of $I L 1 B, I L 6$, and $A v B D$ s are shown in Fig. 4. The expression of $I L 1 B$ and IL6 was upregulated $\sim 500$ and 8 -fold respectively in the 1 and $10 \mu \mathrm{g} / \mathrm{ml} \mathrm{CpG-ODN}$ groups (Fig. 4a and b). No significant effects of CpG-ODN on $A v B D s$ expression were identified (Fig. 4c, d, e, f, g, and h).

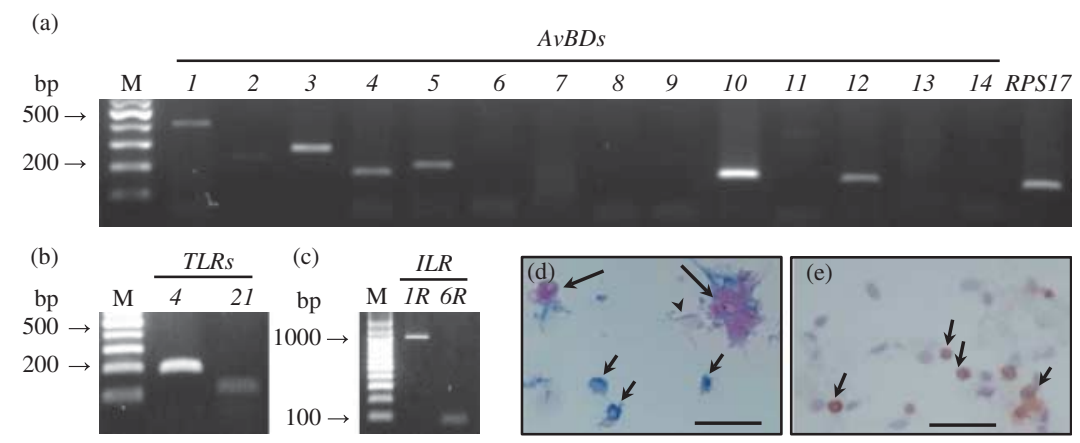

Figure 1 Profile of RT-PCR products for 14 avian $\beta$-defensins (AvBDs) (a), TLR4 and TLR21 (b), receptors of IL1 and IL6 (IL1R1 and IL6R) (c), and cell type identification ( $\mathrm{d}$ and e) in the cultured vaginal cells. The PCR products of $A v B D \mathrm{~s}, T L R \mathrm{~s}$, and IL receptors were electrophoresed on $2 \%$ agarose gel containing ethidium bromide. $M=100$ bp DNA size marker. Micrographs of (d) and (e) show the cultured cells stained by Alciam blue (AB) and Periodic acid-Schiff reaction (PAS), and immunostained by anti-CD45 antibody respectively. In the micrograph of (d), AB-positive (short arrows) and PAS-positive (long arrows) epithelial cells and fibroblast-like cells (arrow heads) are observed. In the micrograph of (e), CD45-positive cells are indicated by arrows. Scale bars represent $50 \mu \mathrm{m}$. 

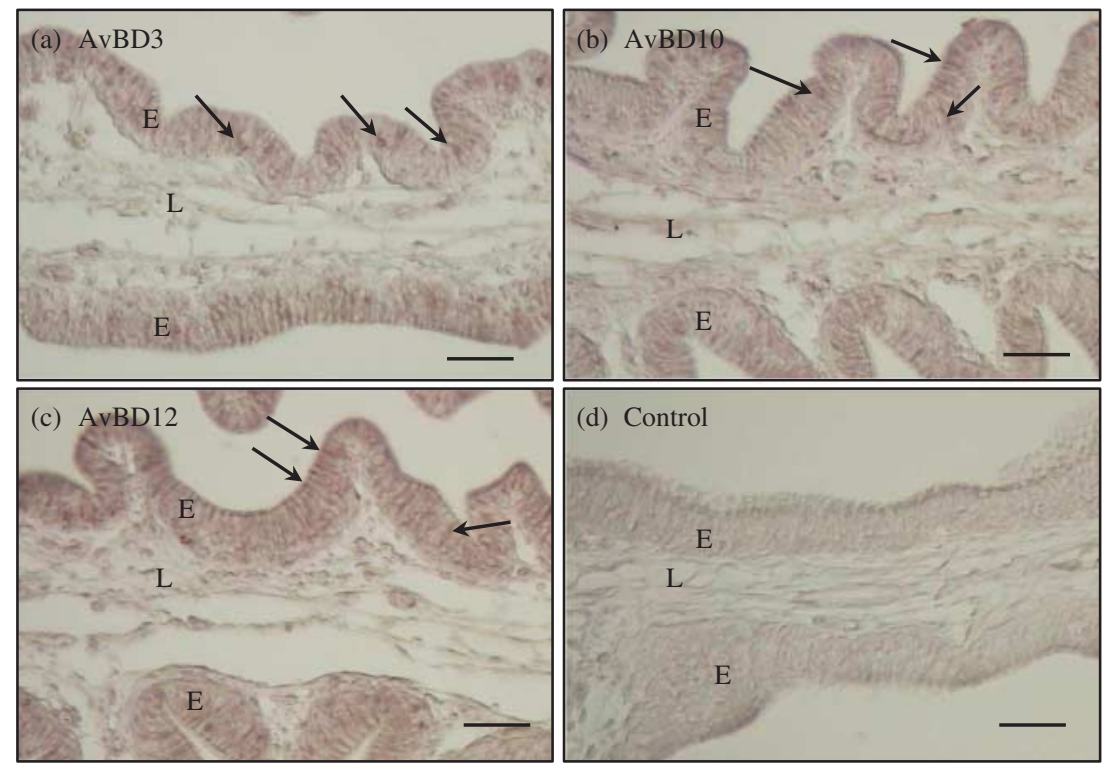

Figure 2 Micrographs of the vagina immunostained for AvBD3, -10, and -12. Immunoreaction products for AvBD3 (a), AvBD10 (b), and AvBD12 (c) are localized in the mucosal epithelium (arrows). Control staining using normal rabbit $\lg G$ in place of primary antibodies shows no positive reaction product (d). E, mucosal epithelium; L, lamina propria. Scale bars represent $30 \mu \mathrm{m}$.

\section{Experiment 2: effects of ILIB and IL6 on the expression of AvBDs in vaginal cells}

Figure 5 shows the effects of different doses of IL1B on the expression of $A v B D s$. The expression of $A v B D 1$ was significantly increased $\sim 2.5$-fold by $10^{2}$ or $10^{3} \mathrm{ng} / \mathrm{ml}$ IL1B (Fig. 5a). The AvBD3 expression showed approximately fivefold change due to $10^{3} \mathrm{ng} / \mathrm{ml}$ IL1B (Fig. 5b). The expression of $A v B D 4,-5,-10$, and -12 was not changed by IL1B (Fig. 5c, d, e, and f).

The effects of IL6 on the $A v B D$ s expression are shown in Fig. 6. The expression of $A v B D 1,-3,-4,-5$, and -10 was not affected by $10^{2}$ or $10^{3} \mathrm{ng} / \mathrm{ml}$ IL6 (Fig. 6a, b, c, d, and e). The $A v B D 12$ expression was significantly higher in the $10^{3} \mathrm{ng} / \mathrm{ml}$ IL6 group than in the $10^{2} \mathrm{ng} / \mathrm{ml}$ IL6 group, whereas the expression of both groups was not different from that of the control $(0 \mathrm{ng} / \mathrm{ml}$ IL6 group) (Fig. 6f).

\section{Discussion}

We report that the expression of proinflammatory cytokines and $A v B D s$ is induced in response to LPS and CpG-ODN in cultured mucosal cells of the vagina and that IL1B also upregulates $A v B D$ s expression. Significant findings were as follows: i) stimulation of the vaginal cells by LPS enhanced the expression of IL $1 B$ and IL6 and also $A v B D 10$ and -12, whereas CpG-ODN upregulated only ILIB and IL6. ii) IL1B upregulated the expression of $A v B D 1$ and -3, but IL6 did not show significant effects on $A v B D$ s expression by the vaginal cells. Previous studies revealed that the expression of $A v B D 1-5$ and $A v B D 8-12$ was identified in fresh vaginal tissue (Abdel Mageed et al. 2008), whereas the expression of $A v B D 1, A v B D 3-5$, and $A v B D 9-14$ was higher than that of $A v B D 2$ and $A v B D 6-8$ in cultured oviductal epithelial cells obtained from the isthmus (Ebers et al. 2009). The current study showed clear RT-PCR products of $A v B D 1,-3,-4,-5,-10$, and - 12 in the cultured vaginal cells. This result partially supports the findings of Ebers et al. (2009) and suggests that the expression of these six $A v B D s$ in the vaginal cells is maintained even after cell culture for $24 \mathrm{~h}$. The cultured cell population involved the epithelial cells, fibroblastlike cells, and leukocytes expressing CD45, a leukocyte common antigen (Symons et al. 1999). Immunoreactive AvBD3, -10, and -12 were localized in the mucosal epithelium, supporting our previous reports that localized immunoreactive AvBD3, -11, and -12 in the mucosal epithelium of the hen vagina (Yoshimura et al. 2007, Abdel Mageed et al. 2009). Although the cells immunoreactive for AvBD1 have not been examined because of the lack of its antibody, many of the AvBD proteins are likely to exist in the mucosal epithelium in the vagina.

The expression of ILIB and IL6 was upregulated by LPS and CpG-ODN in the vaginal cells (Figs 3 and 4). Previous studies reported that TLR1 type 1, 2-5, 7, 15, and 21 were expressed in chicken vaginal tissues (Ozoe et al. 2009, Michailidis et al. 2011). Among these TLRs, TLR4 recognized LPS, whereas TLR21, an avian-specific TLR, recognized unmethylated CpG motifs as TLR9 in mammals (Brownlie \& Allan 2011). The current study further confirmed that TLR4 and 21 expression was detected in cultured vaginal cells (Fig. 1b). These two TLRs play important roles in the defense against Salmonella infection because susceptibility to Salmonella enteritidis is closely related to the responsiveness of three TLRs, namely, TLR4, TLR21, and TLR2 type 1 (Gou et al. 2012). It is likely that the upregulation of IL1B and IL6 expression by LPS is caused by an interaction of LPS 

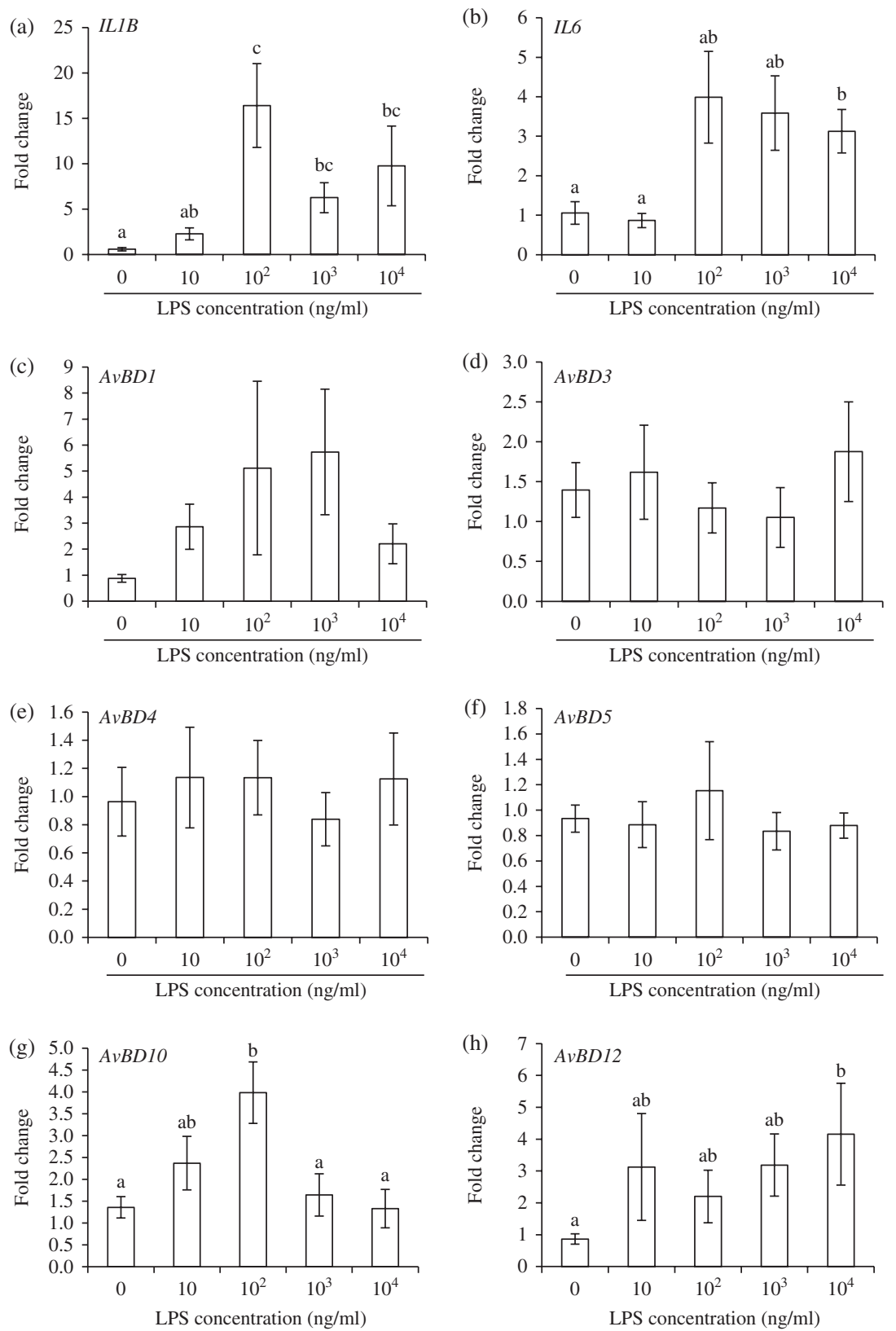

Figure 3 Changes in the expression of ILIB, IL6, and $A v B D s$ in the cultured vaginal cells in response to different doses of LPS. The cultured vaginal cells were stimulated by $0-10^{4} \mathrm{ng} / \mathrm{ml}$ LPS, and the relative expression of $I L 1 B$ and $I L 6$ (a and b) and $A v B D 1,3,4,5,10$, and 12 (c, d, e, f, g, and h) was examined by real-time PCR. Values are mean \pm S.E.M. $(n=6)$. ${ }^{\mathrm{a}, \mathrm{b}, \mathrm{c}}$ The values with different letters are significantly different $(P<0.05)$. with TLR4 in the vaginal cells. The induction of these proinflammatory cytokines by LPS supports the results of our previous in vivo study in the vagina (Ozoe et al. 2009). In addition, it is assumed that the enhancement of ILIB and IL 6 expression by CpG-ODN is mediated by TLR21 expressed in the vaginal cells.

The expression of $A v B D 10$ and -12 in the vaginal cells was elevated by exposure of cells to LPS at $10^{2}$ and $10^{4} \mathrm{ng} / \mathrm{ml}$ respectively (Fig. 3). However, the AvBD10 expression was not increased by $10^{3}$ or $10^{4} \mathrm{ng} / \mathrm{ml}$ LPS. Although the reason why higher dose of LPS did not elevate $A v B D 10$ expression is not known, it may be toxic for the vaginal cells, and disturb the expression of some
$A v B D$ s. We have observed that expression of $A v B D 1,-7$, and -12 in the ovarian follicles were increased by injection of birds with LPS at $1 \mathrm{mg} / \mathrm{kg}$ BW, but not at $2 \mathrm{mg} / \mathrm{kg}$ BW, in laying hens (Subedi et al. 2007). In contrast, CpG-ODN did not show any significant effects on $A v B D$ s expression (Fig. 4). In the downstream of TLRs, signal molecules involved in Myd88-dependent or independent pathways regulate transcriptional factors such as nuclear factor- $\kappa \mathrm{B}$ (NFKB) and activator protein 1 (AP1), leading to the initiation of transcription in the nucleus (Riley \& Nelson 2010). The release of human $\beta$-defensin (hBD) 2 was found to be controlled by phosphoinositide 3 kinase $(\mathrm{PI} 3 \mathrm{~K})$ and $\mathrm{NF} \kappa \mathrm{B}$, whereas 

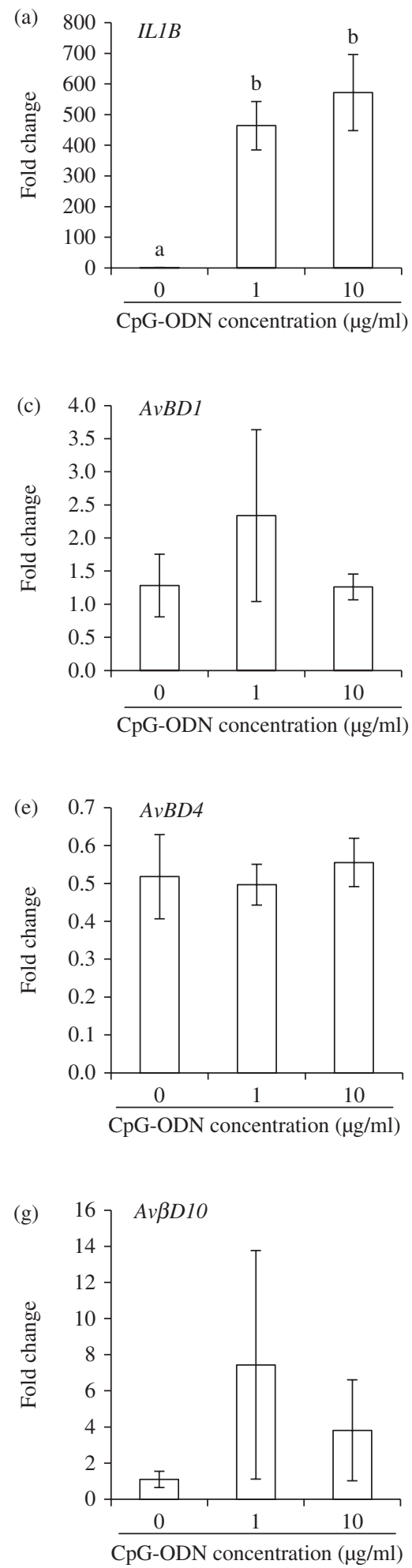
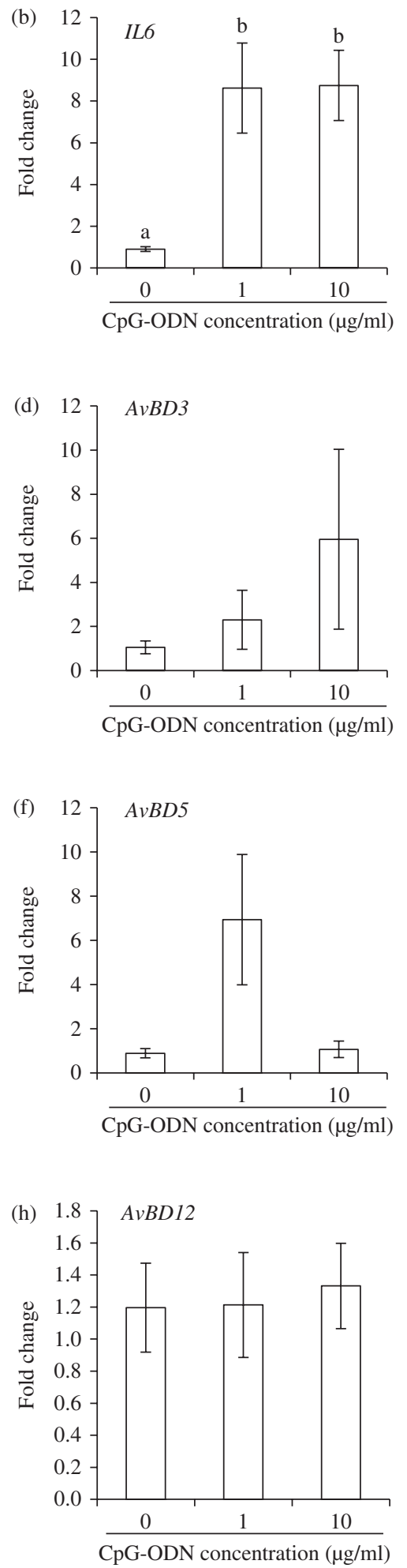

Figure 4 Changes in the expression of ILIB, IL6, and $A v B D s$ in the cultured vaginal cells in response to different doses of CpG-ODN. The cultured vaginal cells were stimulated by $0-10 \mu \mathrm{g} / \mathrm{ml} \mathrm{CpG-ODN}$, and the relative expression of $I L 1 B$ and $I L 6$ (a and $\mathrm{b}$ ) and $A v B D 1,-3,-4,-5,-10$, and -12 (c, d, e, f, g, and h) was examined. Values are mean \pm S.E.M. $(n=6) .{ }^{\mathrm{a}, \mathrm{b}}$ The values with different letters are significantly different $(P<0.05)$.
hBD 3 was triggered via the c-Jun N-terminal kinase (JNK)-AP1 pathway in human lung epithelium (Scharf et al. 2012). Different TLRs may modulate different molecules that activate transcriptional factors, such as IFN regulatory factor 3 (IRF3), $N F_{K} B$, and $A P 1$ (Rhee
2011). Andersen et al. (2006) reported that, in cervical epithelial cells, IL8 expression was upregulated by CpGDNA or poly(I:C), the ligands of TLR9 and TLR3, respectively, whereas IFN $\beta$ and $C C$ chemokine were induced by poly(I:C) but not by CpG-DNA. Thus, it is 

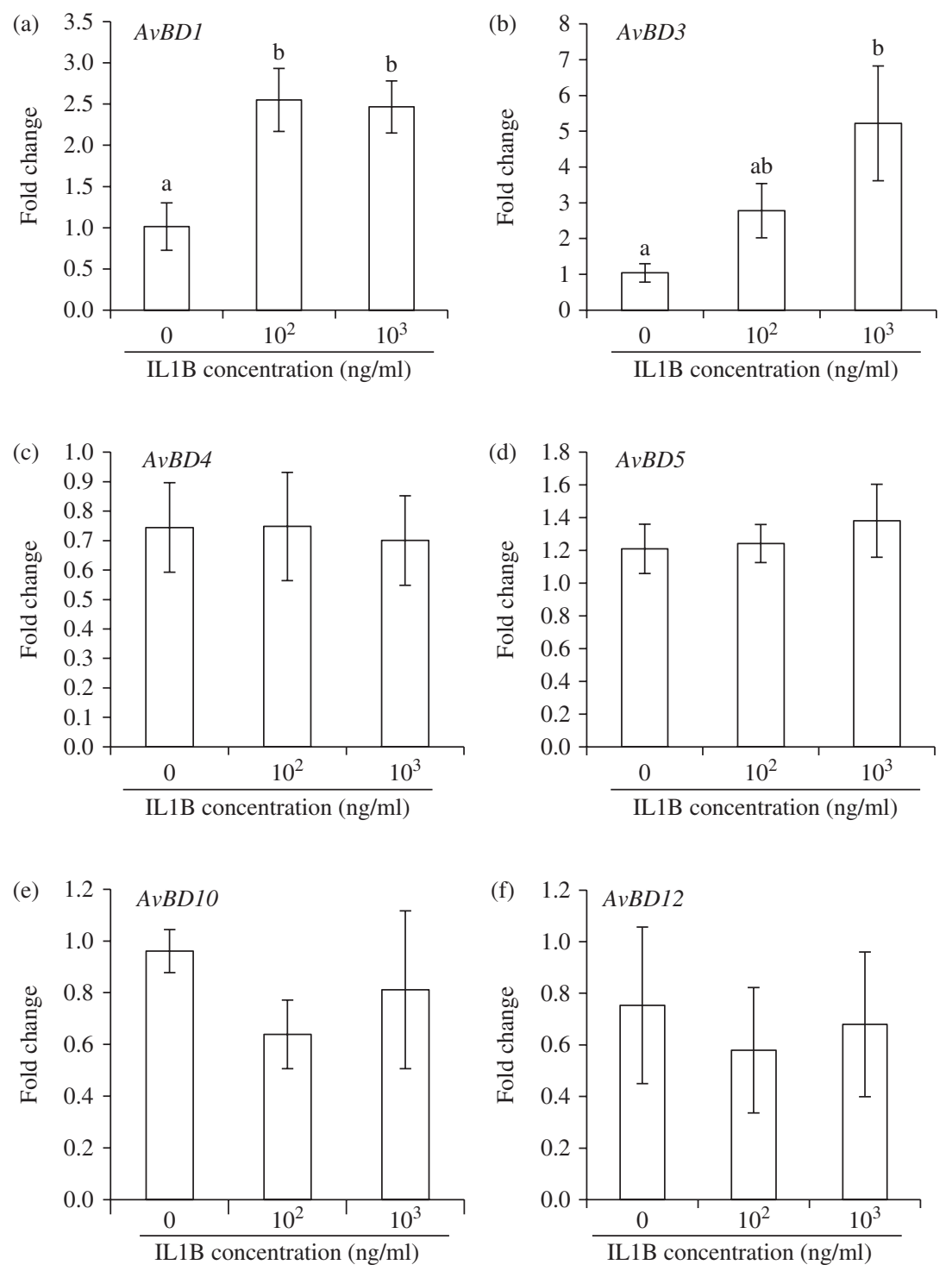

Figure 5 Changes in the expression of $A v B D$ s in the cultured vaginal cells in response to different doses of IL1B. The cultured vaginal cells were stimulated by $0-10^{3} \mathrm{ng} / \mathrm{ml}$ recombinant chicken IL1B and the relative expression of $A v B D 1,-3,-4,-5,-10$, and -12 was examined $(a-f)$. Values are mean \pm S.E.M. $(n=6) .{ }^{\mathrm{a}, \mathrm{b}}$ The values with different letters are significantly different $(P<0.05)$. assumed that the intracellular signaling pathways of LPS and $\mathrm{CpG}-\mathrm{ODN}$ stimulation for transcriptional regulation of $A v B D s$ and IL1B and IL6 are different. LPS might activate a pathway that induces both $A v B D 10$ and -12 as well as ILIB and IL6, whereas CpG-ODN might activate only the pathway for ILIB and IL6.

The expression of $A v B D 1$ and -3 in the vaginal cells was upregulated by exposure to IL1B but not IL6 (Figs 5 and 6). We have reported that, in the theca of hen ovarian follicles, IL1B enhanced the expression of $A v B D 12$, but IL6 did not show significant effects on its expression (Abdelsalam et al. 2012). In humans, hBD expression was induced in keratinocytes and corneal epithelial cells by IL1B (Liu et al. 2002, McDermott et al. 2003). Harder et al. (2000) reported that IL1B and TNF $\alpha$, but not IL6, induced hBD 2 in human respiratory epithelia. Thus, IL1B, but not IL6, likely plays a role in the induction of AvBDs in the hen vagina as in other tissues of hens and mammals. In this study, the expression of ILIR1 and IL6R was identified in cultured vaginal cells (Fig. 1C). Thus, it is suggested that IL1B synthesized in response to bacterial components such as LPS and CpG-ODN stimulated $A v B D 1$ and - 3 expression in an autocrine and/or paracrine manner by interaction with IL1R1 in the vaginal cells. Exposure of the vaginal cells to LPS increased the expression of AvBD10 and -12 (Fig. 3). The intracellular pathway or transcriptional regulation of AvBDs may differ between IL1B and LPS because they induced different AvBDs; namely, IL1Binduced $A v B D 1$ and -3, whereas LPS-induced AvBD10 and -12 .

AvBDs display a wide range of microbicidal or microbiostatic activities against Gram-negative and Gram-positive bacteria as well as fungi (van Dijk et al. 2008). Although it remains unknown whether the target microorganisms differ among the different AvBDs, the 

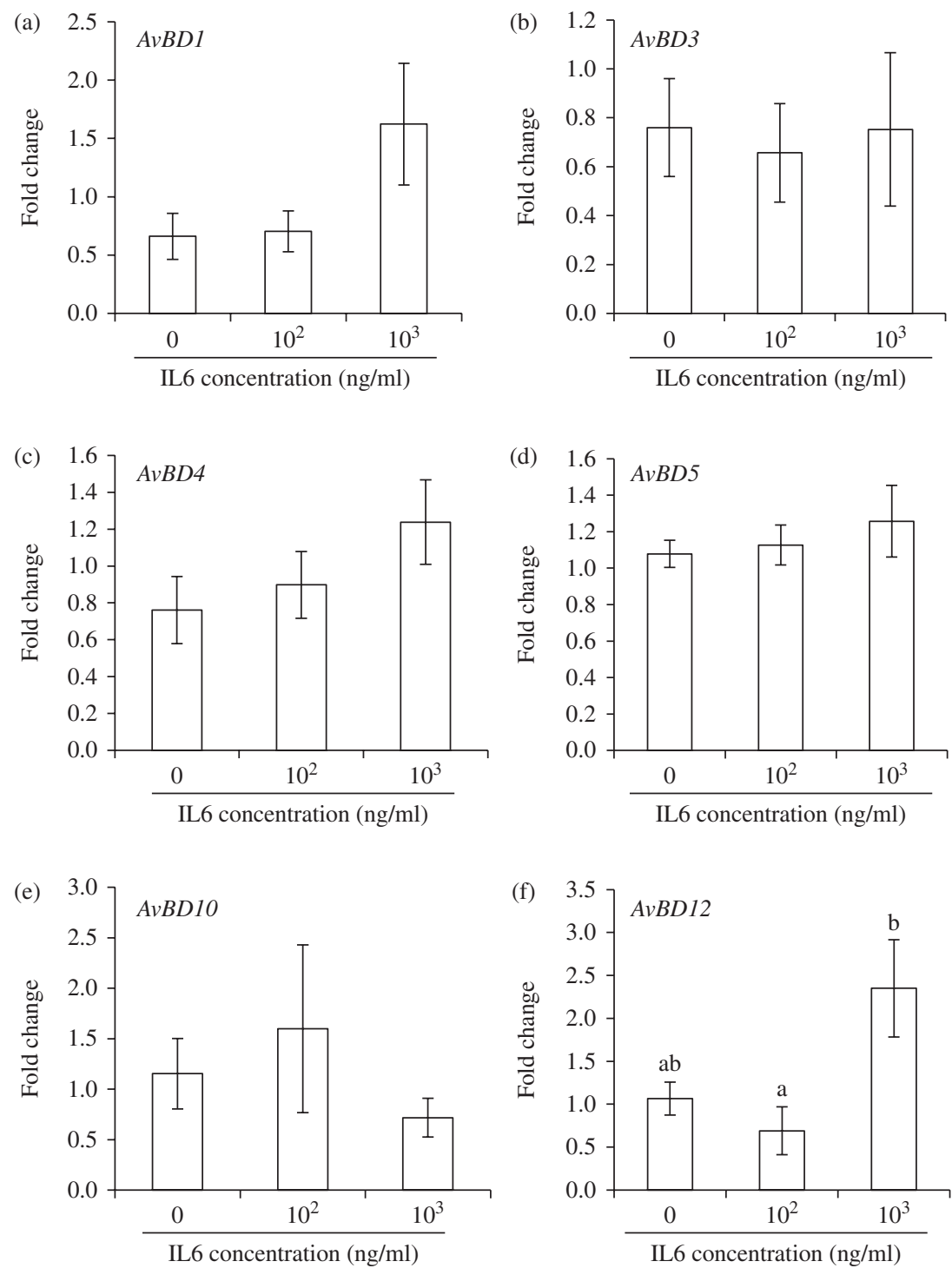

Figure 6 Changes in the expression of $A v B D s$ in the cultured vaginal cells in response to different doses of IL6. The cultured vaginal cells were stimulated by $0-10^{3} \mathrm{ng} / \mathrm{ml}$ recombinant chicken IL 6 , and relative expression of $A v B D 1,-3,-4,-5,-10$, and 12 was examined $(a-f)$. Values are mean \pm s.E.M. $(n=6) .{ }^{\mathrm{a}, \mathrm{b}}$ The values with different letters are significantly different $(P<0.05)$. defense functions against pathogens may be stronger if different AvBDs are induced when tissue is infected. Thus, the ability of vaginal cells to induce various immune molecules including proinflammatory cytokines and different AvBDs may enable the tissue to form a well-developed defense system. We have confirmed that the injection of laying or molting hens with LPS induced the expression of $I L 1 B, I L 6$, and CXCLi2 chemokine in association with $\mathrm{CD} 8+$ and CD4 + T-cell influx, suggesting that a host defense system formed by different immune factors is activated by pathogenic agents in hen vagina (Nii et al. 2011). The cultured mucosal cells of the vagina consisted of different types of cells in this study, and thus some of them are assumed to synthesize proinflammatory cytokines. We assume that immune factors such as IL1B derived from those cells in the vaginal mucosa are responsible for induction of AvBDs.
In conclusion, we suggest that chicken vaginal cells are sensitive to $\mathrm{CpG-ODN}$ to induce proinflammatory cytokines, IL1B and IL6, probably through interaction with TLR21. The synthesized IL1B may induce AvBD1 and -3 in the vaginal cells. Stimulation of the tissue by LPS may induce not only proinflammatory cytokines but also AvBD10 and -12. The ability to induce a variety of immune molecules including proinflammatory cytokines and different AvBDs in response to pathogenic agents may enable the vaginal tissue to form a more efficient defense system against bacterial infection.

\section{Materials and Methods}

\section{Experimental birds}

White Leghorn hens ( $\sim 400$ days old) laying five or more eggs in a sequence were used. They were kept in individual cages under a lighting regimen of $14 \mathrm{~h}$ light: $10 \mathrm{~h}$ darkness and 
provided with feed and water ad libitum. They were killed under anesthesia with sodium pentobarbital and the oviducts were collected at $4 \mathrm{~h}$ after oviposition. This study was carried out in accordance with the Guidelines for Animal Experimentation, Hiroshima University, Japan.

\section{TLR ligands and recombinant IL1B and IL6}

The LPS of Southern Minnesota and synthetic class B CpGODN (2007) (CpG-ODN) were purchased from InvivoGen (San Diego, CA, USA), and recombinant chicken IL1B and IL6 were from $A b D$ Serotec (Oxford, UK). The sequence of CpGODN was 5'-TCGTCGTTGTCGTTTTGTCGTT-3' (Patel et al. 2008). The LPS and CpG-ODN were dissolved in endotoxinfree water and kept at $-20{ }^{\circ} \mathrm{C}$ until use.

\section{Cell culture of vaginal mucosa cells}

Mucosal tissues collected from the middle part of the vagina were washed in sterile PBS containing $10 \mathrm{U} / \mathrm{ml}$ penicillin and $10 \mu \mathrm{g} / \mathrm{ml}$ streptomycin (Cosmo Bio Co., Ltd., Tokyo, Japan). They were cut into small specimens and incubated with a mixture of $400 \mathrm{U} / \mathrm{ml}$ DNase I (Worthington Biochemical Co., Raynham, MA, USA), $320 \mathrm{mg} / \mathrm{ml}$ liberase TL (Roche Diagnostics $\mathrm{GmbH}$ Co.), and $1600 \mathrm{U} / \mathrm{ml}$ hyaluronidase (Nacalai Tesque Co., Kyoto, Japan) in PBS for 30 min at $37{ }^{\circ} \mathrm{C}$ on a water bath. After the cells were dispensed by pipetting, they were filtrated through a stainless steel mesh and washed three times using TCM-199 culture medium (Nissui Pharmaceutical Co., Tokyo, Japan) containing 10\% bovine serum (Biological Ind., Kibbutz Beit Haemek, Israel), $10 \mathrm{U} / \mathrm{ml}$ penicillin, and $10 \mu \mathrm{g} / \mathrm{ml}$ streptomycin (Cosmo Bio Co., Ltd.). The cell viability examined by trypan blue staining was more than $90 \%$. The separated cells were placed on six-well tissue culture plates at a density of $2.5 \times 10^{7}$ vial cells/well, containing $5 \mathrm{ml} \mathrm{TCM}-199$ culture medium, and incubated in a $\mathrm{CO}_{2}$ incubator with $5 \% \mathrm{CO}_{2}$ and $95 \%$ air at $37{ }^{\circ} \mathrm{C}$ for $24 \mathrm{~h}$. Then, the wells were washed to remove nonadherent and dead cells using TCM-199 culture medium.

A part of separated cell samples were also cultured on sterile cover glasses for $24 \mathrm{~h}$ and fixed with $10 \%(\mathrm{v} / \mathrm{v})$ formalin in PBS or cold acetone. The formalin-fixed cells were stained by AB-PAS to identify the mucosal epithelial cells containing mucopolysaccharide. The cell samples fixed with acetone were used for identification of leukocytes by immunocytochemistry for CD45, a leukocyte common antigen (Symons et al. 1999). They were incubated overnight with mouse anti-chicken CD45 antibody (Southern Biotech, Birmingham, AL, USA) diluted at 1:500 in PBS. Then, they were incubated with biotinylated antimouse IgG and avidin-biotin-peroxidase complex in Vecta Stain ABC mouse IgG kit (Vector Lab., Inc., Burlingame, CA, USA) for $30 \mathrm{~min}$ and $1 \mathrm{~h}$ respectively. Immunoreaction products were visualized by incubating the samples with $0.02 \%$ (wt/vol) 3',3'-diaminobenzidine tetrahydrochloride and $0.005 \%$ (vol/vol) $\mathrm{H}_{2} \mathrm{O}_{2}$ in $0.05 \mathrm{M}$ Tris- $\mathrm{HCl}$, $\mathrm{pH} 7.6$, $\left(\mathrm{DAB}-\mathrm{H}_{2} \mathrm{O}_{2}\right)$. They were dehydrated and mounted. These staining of cultured cells were repeated in duplicate.

\section{Immunohistochemistry for AvBDs}

The vaginal tissues of the experimental birds $(n=3)$ were fixed in $10 \%(\mathrm{v} / \mathrm{v})$ formalin in PBS and processed for paraffin sections ( $4 \mu \mathrm{m}$ in thickness) that were air-dried in MAS-coated precleaned slides (Matsunami Glass, Inc., Osaka, Japan). The immunohistochemistry was performed using rabbit antibodies to AvBD3, -10 , and -12 for primary antibodies that were used in our previous studies (Abdel Mageed et al. 2009, Abdelsalam et al. 2010). Vecta Stain ABC rabbit IgG kit (Vector Lab., Inc.) was used to identify the immunoreaction products. Briefly, after deparaffinization, antigen retrieval of the sections was performed by autoclaving them for $1 \mathrm{~min}$ in $0.1 \mathrm{M}$ citric acid, $\mathrm{pH}$ 6.0. They were incubated with blocking solution $(1.5 \%$ (vol/vol) normal goat serum in PBS) for $1 \mathrm{~h}$ at room temperature. Then sections were incubated overnight with antibodies to AvBD3, -10, or -12 diluted at a concentration of $20 \mu \mathrm{g} / \mathrm{ml}$ followed by washing with PBS $(3 \times 5 \mathrm{~min})$. The sections were then incubated with biotinylated anti-rabbit $\lg \mathrm{G}$ and avidin-biotin-peroxidase complex for $1 \mathrm{~h}$ each and were washed with PBS. Immunoprecipitates were visualized by incubating the sections with $\mathrm{DAB}-\mathrm{H}_{2} \mathrm{O}_{2}$. The sections were dehydrated and covered and examined under a light microscope with a Nomarsky filter (Nikon Eclipse E600; Nikon, Tokyo, Japan). Control staining was carried out simultaneously in which the first antibody was replaced with normal rabbit IgG.

\section{Stimulation of cultured cells}

In experiment 1, the effects of LPS and CpG-ODN on the expression of proinflammatory cytokines and $A v B D s$ in the vaginal cells were examined. Different doses of LPS $\left(0-10^{4} \mathrm{ng} / \mathrm{ml}\right)$ or CpG-ODN $(0-10 \mu \mathrm{g} / \mathrm{ml})$ were added to the wells containing the cells cultured for $24 \mathrm{~h}$. After $3 \mathrm{~h}$ incubation, the expression of $I L 1 B, I L 6$, and $A v B D 1, A v B D 3-5$, $A v B D 10$, and $A v B D 12$ was examined. We applied incubation for $3 \mathrm{~h}$ because the expression of $I L 1 B, I L 6$, and $A v B D s$ responded to LPS by $3 \mathrm{~h}$ in the theca in our previous study (Abdelsalam et al. 2012). In experiment 2, the effects of IL1B and IL6 on the expression of $A v B D s$ were examined. The cultured cells were stimulated by $0-10^{3} \mathrm{ng} / \mathrm{ml}$ IL1B or $0-10^{3} \mathrm{ng} / \mathrm{ml}$ IL6 for $3 \mathrm{~h}$. In each experiment, trials were repeated six times.

\section{RNA isolation and CDNA preparation}

Total RNA was extracted from the cultured vaginal cells using Sepasol RNA I Super (Nacalai Tesque, Inc.) in each experiment as described previously ( $\mathrm{Nii}$ et al. 2011). The extracted total RNA was dissolved in TE buffer (0.01 M Tris- $\mathrm{HCl}$, pH 8.0, and $1 \mathrm{mM}$ EDTA). Samples were treated with RQ1 RNase-free DNase (Promega Co.) in a $10 \mu \mathrm{l}$ reaction mixture $(0.5 \mu \mathrm{g}$ of total RNA, $1 \times$ DNase buffer, and $1 \cup$ DNase) on a PTC-100 programmable thermal controller (MJ Research, Inc., Waltham, MA, USA), programmed at $37^{\circ} \mathrm{C}$ for $45 \mathrm{~min}$ and $65^{\circ} \mathrm{C}$ for $10 \mathrm{~min}$. The concentration of RNA in each sample was measured using Gene Quant Pro (Amersham Pharmacia Biotech). RNA samples were reverse transcribed using ReverTra 
Ace (Toyobo Co. Ltd., Osaka, Japan) according to the instructions of the manufacturer. The reaction mixture $(10 \mu \mathrm{l})$ consisted of $0.5 \mu \mathrm{g}$ of total RNA, $1 \times$ RT buffer, $1 \mathrm{mM} d \mathrm{dNTP}$ mixture, $20 \cup$ RNase inhibitor, $0.5 \mu$ g oligo(dT) 20 primer, and $50 \mathrm{U}$ ReverTra Ace. The RT was performed at $42{ }^{\circ} \mathrm{C}$ for $30 \mathrm{~min}$ followed by heat inactivation for $5 \mathrm{~min}$ at $99^{\circ} \mathrm{C}$ using the PTC100 Programmable Thermal Controller.

PCR to analyze the expression of AvBDs, TLR4 and TLR21, and ILIR1 and IL6R was performed using Takara Ex Taq (Takara Bio, Inc., Shiga, Japan) according to the protocol of the manufacturer on a PTC-100 Programmable Thermal Controller. The primers for target genes and ribosomal protein S17 (RPS17) used in this study are shown in Table 1 . The PCR mixture $(25 \mu \mathrm{l})$ contained a $0.5 \mu \mathrm{l}$ aliquot of cDNA, $1 \times$ PCR buffer, $1.5 \mathrm{mM}$ $\mathrm{MgCl}_{2}, 0.2 \mathrm{mM}$ each dNTP, $1.25 \cup$ Takara Ex Taq, and $0.5 \mu \mathrm{M}$ each primer. The cycle parameters were denaturated at $94{ }^{\circ} \mathrm{C}$ for $30 \mathrm{~s}, 30$ cycles (for IL1R1 and RPS17), or 40 cycles (AvBD114, TLR4, -21, and IL6R); annealing at $56^{\circ} \mathrm{C}$ (for $A v B D 3$,
$A v B D 5-7, A v B D 10$, and $A v B D 14), 58{ }^{\circ} \mathrm{C}$ (AvBD1, -2, -8, -9, -11, -12, TLR4, -21, and IL1R1), or $60^{\circ} \mathrm{C}$ (AvBD4, -13, IL6R, and $R P S 17$ ) for $30 \mathrm{~s}$, and extension at $72{ }^{\circ} \mathrm{C}$ for $1 \mathrm{~min}$ followed by final extension at $72{ }^{\circ} \mathrm{C}$ for $6 \mathrm{~min}$. The PCR products were separated by electrophoresis on a $2 \%(\mathrm{w} / \mathrm{v})$ agarose gel containing $0.4 \%(\mathrm{w} / \mathrm{v})$ ethidium bromide. Analysis was performed in duplicate using different cultured cell samples.

\section{Quantitative real-time PCR}

Real-time PCR was performed using the Roche Light Cycler system (Roche Applied Science) as described in our previous study (Abdelsalam et al. 2012). The reaction mixture $(20 \mu \mathrm{l})$ consisting of $1 \mu \mathrm{l}$ cDNA, $1 \times$ SYBR Premix EX Taq (Takara Bio, Inc.), and $0.5 \mu \mathrm{M}$ each primer was placed into $20 \mu$ l capillaries (Roche Diagnostics $\mathrm{GmbH}$ ). The thermal protocols for PCR were at $95^{\circ} \mathrm{C}$ for $5 \mathrm{~s} ; 60{ }^{\circ} \mathrm{C}$ for $20 \mathrm{~s}$ (AvBD10 and RPS17), $60^{\circ} \mathrm{C}$ for $30 \mathrm{~s}$ (AvBD1 and $A v B D 4)$, or $63{ }^{\circ} \mathrm{C}$ for $30 \mathrm{~s}$ (AvBD3, -5, and

Table 1 Primer sequences for AvBDs, IL1B, IL6, TLRs, IL1R1, IL6R, and RPS17.

\begin{tabular}{|c|c|c|c|}
\hline Target genes & Sequences $5^{\prime}-3^{\prime}$ & Accession no. & References \\
\hline$A v B D 1$ & $\begin{array}{l}\text { F: AAACCATGCGGATCGTGTACCTGC } \\
\text { R: CAATGCTAAACTGCACACCTTTA }\end{array}$ & AF033335 & Subedi et al. (2007) \\
\hline$A v B D 2$ & $\begin{array}{l}\text { F: GTTCTGTAAAGGAGGGTCCTGCCAC } \\
\text { R: ACTCTACAACACAAAACATATTGC }\end{array}$ & AF033336 & Subedi et al. (2007) \\
\hline$A v B D 3$ & $\begin{array}{l}\text { F: CTGCCGCTTCCCACACATAG } \\
\text { R: GCAATGCCAAACTGCACGCCTTTA }\end{array}$ & NM_204650 & Subedi et al. (2007) \\
\hline$A v B D 4$ & $\begin{array}{l}\text { F: ATCGTGCTCCTCTTTGTGGCAGTTCA } \\
\text { R: CTACAACCATCTACAGCAAGAATACT }\end{array}$ & NM_001001610 & Subedi et al. (2007) \\
\hline$A v B D 5$ & $\begin{array}{l}\text { F: ATGCAGATCCTGCCTGCCTCTCTCTTTGCT } \\
\text { R: TCAGGAATACCATCGGCTCCGGCAGCAGAA }\end{array}$ & NM_001001608 & Subedi et al. (2007) \\
\hline$A v B D 6$ & $\begin{array}{l}\text { F: GATCCTTTACCTGCTGCTGTCT } \\
\text { R: TCCTCACACAGCAAGATTTTAGTC }\end{array}$ & NM_00100193 & Subedi et al. (2007) \\
\hline$A v B D 7$ & $\begin{array}{l}\text { F: CTGCTGTCTGTCCTCTTTGTGG } \\
\text { R: CATTTGGTAGATGCAGGAAGGA }\end{array}$ & NM_001001194 & Subedi et al. (2007) \\
\hline$A v B D 8$ & $\begin{array}{l}\text { F: TTCTCCTCACTGTGCTCCAA } \\
\text { R: AAGGCTCTGGTATGGAGGTG }\end{array}$ & NM_001001781 & Watanabe et al. (2011) \\
\hline$A v B D 9$ & $\begin{array}{l}\text { F: ATGAGAATCCTTTTCTTCCTTGTTGC } \\
\text { R: TTAGGAGCTGGGTGCCCATTTGCAGC }\end{array}$ & NM_001001611 & Subedi et al. (2007) \\
\hline$A v B D 10$ & $\begin{array}{l}\text { F: CTGTTCTCCTCTTCCTCTTCCAG } \\
\text { R: AATCTTGGCACAGCAGTTTAACA }\end{array}$ & NM_001001609 & Subedi et al. (2007) \\
\hline$A v B D 11$ & $\begin{array}{l}\text { F: ACTGCATCCGTTCCAAAGTCTG } \\
\text { R: GTCCCAGCTGTTCTTCCAG }\end{array}$ & NM_001001779 & Ebers et al. (2009) \\
\hline$A v B D 12$ & $\begin{array}{l}\text { F: GGAACCTTTGTTTCGTGTTCA } \\
\text { R: GAGAATGACGGGTTCAAAGC }\end{array}$ & AY534898 & Abdelsalam et al. (2012) \\
\hline$A v B D 13$ & $\begin{array}{l}\text { F: CATCGTTGTCATTCTCCTCCTC } \\
\text { R: ACTTGCAGCGTGTGGGAGTTG }\end{array}$ & NM_001001780 & Subedi et al. (2007) \\
\hline$A v B D 14$ & $\begin{array}{l}\text { F: CATATTCСТССТGTTTCTTGTTCTC } \\
\text { R: GCCAGTCCATTGTAGCAGGT }\end{array}$ & AM402954 & Watanabe et al. (2011) \\
\hline TLR4 & $\begin{array}{l}\text { F: AGTCTGAAATTGCTGAGCTCAAAT } \\
\text { R: GCGACGTTAAGCCATGGAAG }\end{array}$ & AY064697 & Zhang et al. (2012) \\
\hline TLR21 & $\begin{array}{l}\text { F: TGCCССТСССАСТGCTGTCСАCT } \\
\text { R: AAAGGTGCCTTGACATCCT }\end{array}$ & NM001030558 & Zhang et al. (2012) \\
\hline IL $1 B$ & $\begin{array}{l}\text { F: GGGCATCAAGGGCTACAA } \\
\text { R: CTGTCCAGGCGGTAGAAGAT }\end{array}$ & NM_204524 & Nii et al. (2011) \\
\hline IL6 & $\begin{array}{l}\text { F: AGAAATCCСТCСТCGCСАAT } \\
\text { R: AAATAGCGAACGGCCСТCA }\end{array}$ & NM_204628.1 & Nii et al. (2011) \\
\hline IL $1 R 1$ & $\begin{array}{l}\text { F: TTGTTCAGTGCTGAAGAATGTGTTATTTG } \\
\text { R: ACGAATGTTCTGAACTGGGTGTTC }\end{array}$ & NM_205485 & $*$ \\
\hline IL6R & $\begin{array}{l}\text { F: TGAGGATGATCCCTACGGCTATG } \\
\text { R: CCGGCATCATCAGCAGTGT }\end{array}$ & NM_001044675 & $*$ \\
\hline RPS17 & $\begin{array}{l}\text { F: AAGCTGCAGGAGGAGGAGAGG } \\
\text { R: GGTTGGACAGGCTGCCGAAGT }\end{array}$ & NM_204217 & Nii et al. (2011) \\
\hline
\end{tabular}

$\mathrm{F}$, forward; $\mathrm{R}$, reverse. ${ }^{*} \mathrm{PCR}$ products were sequenced for verification. 
-12) and then $72{ }^{\circ} \mathrm{C}$ for $1 \mathrm{~min}(A v B D 1, A v B D 3-5$, and $A v B D 12)$. Real-time PCR data were analyzed using the $2^{-\triangle \triangle C T}$ method to calculate the relative level of mRNA in each sample and are expressed as ratios in relation to the RPS17 housekeeping gene (Livak \& Schmittgen 2001). The RNA samples obtained from unstimulated cells were used as standards.

\section{Statistical analysis}

The relative expression of $I L 1 B, I L 6$, and $A v B D 1, A v B D 3-5$, $A v B D 10$, and $A v B D 12$ is expressed as the mean \pm S.E.M. $(n=6)$. The significance of differences in the relative expression among different dose groups within LPS, CpG-ODN, IL1B, or IL6 treatments was examined by one-way ANOVA followed by Tukey's test or the Kruskal-Wallis test. Differences were considered significant at $P<0.05$.

\section{Declaration of interest}

The authors declare that there is no conflict of interest that could be perceived as prejudicing the impartiality of the research reported.

\section{Funding}

This work was supported by a Grant-in-Aid for Scientific Research from the Japan Society for the Promotion of Science.

\section{References}

Abdel Mageed AM, Isobe N \& Yoshimura Y 2008 Expression of avian $\beta$-defensins in the oviduct and effects of lipopolysaccharide on their expression in the vagina of hens. Poultry Science 87 979-984. (doi:10.3382/ps.2007-00283)

Abdel Mageed AM, Isobe N \& Yoshimura Y 2009 Immunolocalization of avian $\beta$-defensins in the hen oviduct and their changes in the uterus during eggshell formation. Reproduction 138 971-978. (doi:10.1530/ REP-09-0181)

Abdelsalam M, Isobe N \& Yoshimura Y 2010 Changes in the localization of immunoreactive avian $\beta$-defensins $-8,-10$ and -12 in hen ovarian follicles during follicular growth. Journal of Poultry Science 47 77-84. (doi:10.2141/jpsa.009083)

Abdelsalam M, Isobe N \& Yoshimura Y 2012 Effects of lipopolysaccharide and interleukins on the expression of avian $\beta$-defensins in hen ovarian follicular tissue. Poultry Science 91 2877-2884. (doi:10.3382/ps.201202312)

Andersen JM, Al-Khairy D \& Ingalls RR 2006 Innate immunity at the mucosal surface: role of Toll-like receptor 3 and Toll-like receptor 9 in cervical epithelial cell responses to microbial pathogens. Biology of Reproduction 74 824-831. (doi:10.1095/biolreprod.105.048629)

Arend WP, Palmer G \& Gabay C 2008 IL-1, IL-18, and IL-33 families of cytokines. Immunological Reviews 223 20-38. (doi:10.1111/j.1600065X.2008.00624.x)

Bauer S, Kirschning CJ, Hächer H, Redecke V, Hausmann S, Akira S, Wagner H \& Lipford GB 2001 Human TLR9 confers responsiveness to bacterial DNA via species-specific CpG motif recognition. PNAS 98 9237-9242. (doi:10.1073/pnas.161293498)

Brownlie R \& Allan B 2011 Avian Toll-like receptors. Cell and Tissue Research 343 121-130. (doi:10.1007/s00441-010-1026-0)

Brownlie R, Zhu J, Allan B, Mutwiri GK, Babiuk LA, Potter A \& Griebel P 2009 Chicken TLR21 acts as a functional homologue to mammalian TLR9 in the recognition of CpG oligodeoxynucleotides. Molecular Immunology 46 3163-3170. (doi:10.1016/j.molimm.2009.06.002)
Chomarat P, Banchereau J, Davoust J \& Palucka AK 2000 IL-6 switches the differentiation of monocytes from dendritic cells to macrophages. Nature Immunology 1 510-514. (doi:10.1038/82763)

Ebers KL, Zhang CY, Zhang MZ, Bailey RH \& Zhang S 2009 Transcriptional profiling avian $\beta$-defensins in chicken oviduct epithelial cells before and after infection with Salmonella enterica serovar Enteritidis. BMC Microbiology 9 153. (doi:10.1186/1471-2180-9-153)

Ferro PJ, Swaggerty CL, Kaiser P, Pevzner IY \& Kogut MH 2004 Heterophils isolated from chickens resistant to extraintestinal Salmonella enteritidis infection express higher levels of proinflattatory cytokine mRNA following infection than heterophils from susceptibla chickens. Epidemiology and Infection 132 1029-1037. (doi:10.1017/S09502 68804002687)

Gou Z, Liu R, Zhao G, Zheng M, Li P, Wang H, Zhu Y, Chen J \& Wen J 2012 Epigenetic modification of TLRs in leukocytes is associated with increased susceptibility to Salmonella enteritidis in chickens. PLoS ONE 7 e33627. (doi:10.1371/journal.pone.0033627)

Harder J, Meyer-Hoffert U, Teran LM, Schwichtenberg L, Bartels J, Maune S \& Schröder JM 2000 Mucoid Pseudomonas aeruginosa, TNF- $\alpha$, and IL-1 $\beta$, but not IL-6, induce human $\beta$-defensin 2 in respiratory epithelia. American Journal of Respiratory Cell and Molecular Biology 22 714-721. (doi:10.1165/ajrcmb.22.6.4023)

He H, Crippen TL, Farnell MB \& Kogut MH 2003 Identification of CpG oligodeoxynucleotide motifs that stimulate nitric oxide and cytokine production in avian macrophage and peripheral blood mononuclear cells. Developmental and Comparative Immunology 27 621-627. (doi:10.1016/S0145-305X(03)00013-2)

Hemmi H, Takeushi O, Kawai T, Kaisho T, Sato S, Sanjo H, Matsumoto M, Hoshino K, Wagner H, Takeda K et al. 2000 Toll-like receptor recognizes bacterial DNA. Nature 408 740-745. (doi:10.1038/35047123)

Krieg AM, Yi AK, Matson S, Waldschmidt TJ, Bishop GA, Teasdale R, Koretzky GA \& Klinman DM 1995 CpG motifs in bacterial DNA trigger direct B-cell activation. Nature 374 546-549. (doi:10.1038/374546a0)

Liu AY, Destoumieux D, Wong AV, Park CH, Valore EV, Liu L \& Ganz T 2002 Human $\beta$-defensin-2 production in keratinocytes is regulated by interleukin-1, bacteria, and the state of differentiation. Journal of Investigative Dermatology 118 275-281. (doi:10.1046/j.0022-202x. 2001.01651.x)

Livak KJ \& Schmittgen TD 2001 Analysis of relative gene expression data using real-time quantitative PCR and the $2(-$ Delta Delta $C(\mathrm{~T}))$ method. Methods 25 402-408. (doi:10.1006/meth.2001.1262)

Lynn DJ, Higgs R, Lloyd AT, O'Farrelly C, Hervé-Grépinet V, Nys Y, Brinkman FS, Yu PL, Soulier A, Kaiser P et al. 2007 Avian $\beta$-defensin nomenclature: a community proposed update. Immunology Letters $\mathbf{2 2 0}$ 86-89. (doi:10.1016/j.imlet.2007.03.007)

McDermott AM, Redfern RL, Zhang B, Pei Y, Huang L \& Proske RJ 2003 Defensin expression by the cornea: multiple signalling pathways mediate IL-1 $\beta$ stimulation of hBD-2 expression by human corneal epithelial cells. Investigative Ophthalmology \& Visual Science $4 \mathbf{4}$ 1859-1865. (doi:10.1167/iovs.02-0787)

Michailidis G, Theodoridis A \& Avdi M 2011 Effects of sexual maturation and Salmonella infection on the expression of Toll-like receptors in the chicken vagina. Animal Reproduction Science $123234-2341$. (doi:10.1016/j.anireprosci.2011.01.010)

Nii T, Sonoda Y, Isobe N \& Yoshimura Y 2011 Effects of lipopolysaccharide on the expression of proinflammatory cytokines and chemokines and the subsequent recruitment of immunocompetent cells in the oviduct of laying and molting hens. Poultry Science 90 2332-2341. (doi:10.3382/ ps.2011-01596)

Okada M, Sakaguchi N, Yoshimura N, Hara H, Shimizu K, Yoshida N, Yoshizaki K, Kishimoto S, Yamamura Y \& Kishimoto T 1983 B cell growth factors and $B$ cell differentiation factor from human $T$ hybridomas. Two distinct kinds of B cell growth factor and their synergism in B cell proliferation. Journal of Experimental Medicine 157 583-590. (doi:10.1084/jem.157.2.583)

Ozoe A, Isobe $\mathbf{N} \&$ Yoshimura Y 2009 Expression of Toll-like receptors (TLRs) and TLR4 response to lipopolysaccharide in hen oviduct. Veterinary Immunology and Immunopathology 127 259-268. (doi:10.1016/j.vetimm.2008.10.325)

Patel BA, Gomis S, Dar A, Willson PJ, Babiuk LA, Potter A, Mutwiri G \& Tikoo SK 2008 Oligodeoxynucleotides containing CpG motifs 
(CpG-ODN) predominantly induce Th1-type immune response in neonatal chicks. Developmental and Comparative Immunology 32 1041-1049. (doi:10.1016/j.dci.2008.02.007)

Pioli PA, Weaver LK, Schaefer TM, Wright JA, Wira CR \& Guyre PM 2006 Lipopolysaccharide-induced IL-1 $\beta$ production by human uterine macrophages up-regulates uterine epithelial cell expression of human $\beta$-defensin 2. Journal of Immunology 176 6647-6655.

Rhee SH 2011 Basic and translational understandings of microbial recognition by Toll-like receptors in the intestine. Journal of Neurogastroenterology and Motility 17 28-34. (doi:10.5056/jnm.2011.17.1.28)

Riley JK \& Nelson DM 2010 Toll-like receptors in pregnancy disorders and placental dysfunction. Clinical Reviews in Allergy \& Immunology 39 185-193. (doi:10.1007/s12016-009-8178-2)

Scharf S, Zahlten J, Szymanski K, Hippenstiel S, Suttorp N \& N'Guessan PD 2012 Streptococcus pneumoniae induces human $\beta$-defensin- 2 and -3 in human lung epithelium. Experimental Lung Research 38 100-110. (doi:10.3109/01902148.2011.652802)

Selsted ME \& Ouellette AJ 2005 Mammalian defensins in the antimicrobial immune response. Nature Immunology 6551-557. (doi:10.1038/ni1206)

Shin JS, Kim CW, Kwon YS \& Kim JC 2004 Human $\beta$-defensin 2 is induced by interleukin-1 $\beta$ in the corneal epithelial cells. Experimental \& Molecular Medicine 36 204-210. (doi:10.1038/emm.2004.28)

Staeheli P, Puehler F, Schneider K, Göbel TW \& Kaspers B 2001 Cytokines of birds: conserved function-A largely different look. Journal of Interferon \& Cytokine Research 21 993-1010. (doi:10.1089/107999001317205123)

Subedi K, Isobe N, Nishibori M \& Yoshimura Y 2007 Changes in the expression of gallinacins, antimicrobial peptides, in ovarian follicles during follicular growth and in response to lipopolysaccharide in laying hens (Gallus domesticus). Reproduction 133 127-133. (doi:10.1530/ REP-06-0083)
Sugiarto H \& Yu PL 2004 Avian antimicrobial peptides: the defensing role of $\beta$-defensins. Biochemical and Biophysical Research Communications 323 721-727. (doi:10.1016/j.bbrc.2004.08.162)

Symons A, Willis AC \& Barclay AN 1999 Domain organization of the extracellular region of CD45. Protein Engineering 12 885-892. (doi:10.1093/protein/12.10.885)

Van Dijk A, Veldhuizen EJ \& Haagsman HP 2008 Avian defensins. Veterinary Immunology and Immunopathology 124 1-18. (doi:10.1016/ j.vetimm.2007.12.006)

Wagner H 1999 Bacterial CpG DNA activates immune cells to signal infectious danger. Advance Immunology 73 329-368.

Watanabe Y, Isobe N \& Yoshimura Y 2011 Detection of avian $\beta$-defensins mRNA and proteins in male reproductive organs in chicken. Journal of Poultry Science 48 275-280. (doi:10.2141/jpsa.011042)

Yang D, Biragyn A, Kwak LW \& Oppenheim JJ 2002 Mammalian defensins in immunity. More than just microbicidal. Trends in Immunology 23 291-296. (doi:10.1016/S1471-4906(02)02246-9)

Yoshimura Y, Tsuchida M, Nakamura J, Saito T, Isobe N \& lijima N 2007 Preparation and application for immunocytochemistry of antibody to gallinacin-3, an antimicrobial peptide, in chicken. Journal of Poultry Science 44 433-438. (doi:10.2141/jpsa.44.433)

Zhang M, Nii T, Isobe N \& Yoshimura Y 2012 Expression of Toll-like receptors and effects of lipopolysaccharide on the expression of proinflammatory cytokines and chemokine in the testis and epididymis of roosters. Poultry Science 91 1997-2003. (doi:10.3382/ps.2012-02236)

Received 20 December 2012

First decision 21 February 2013

Accepted 24 April 2013 